Provided for non-commercial research and education use. Not for reproduction, distribution or commercial use.

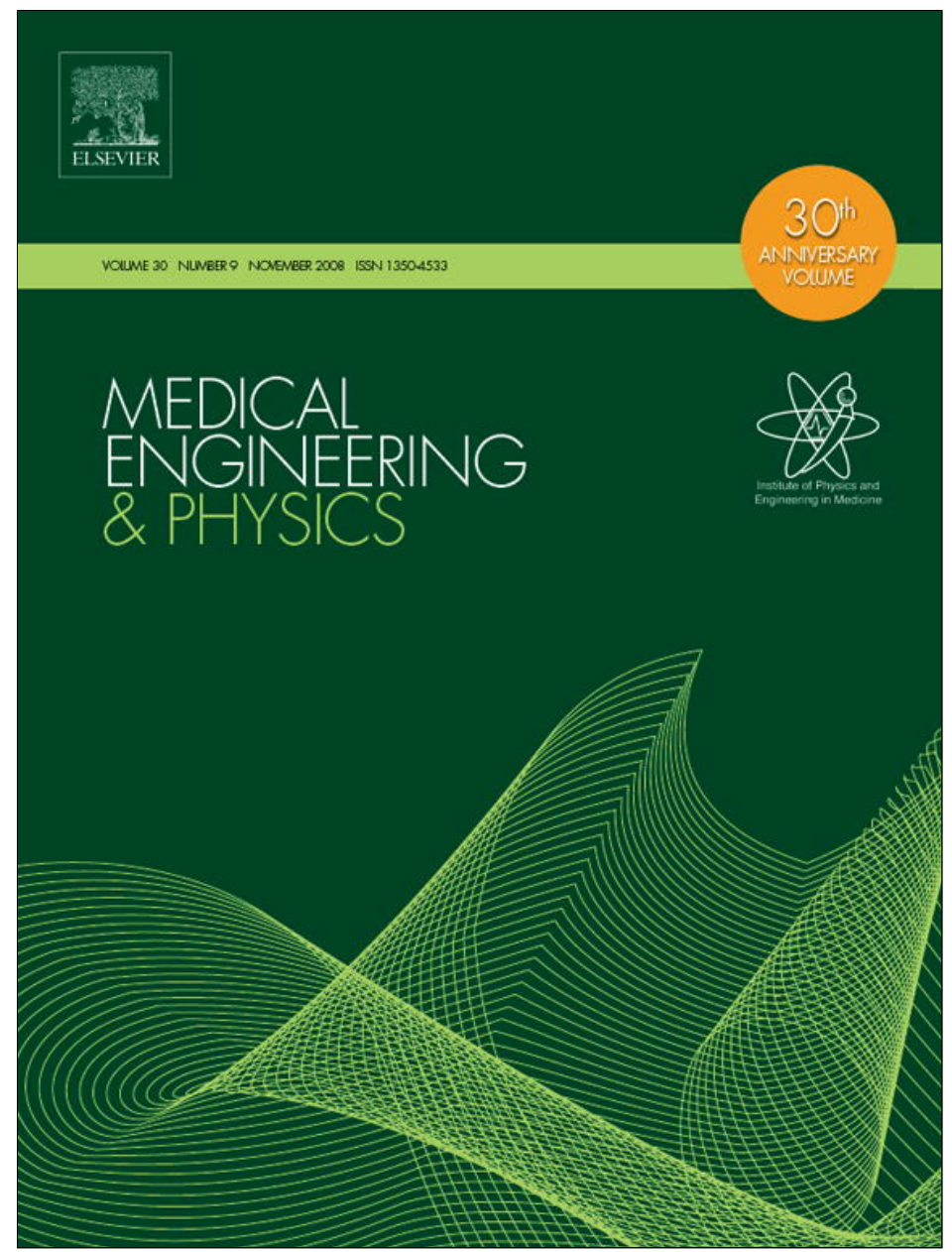

This article appeared in a journal published by Elsevier. The attached copy is furnished to the author for internal non-commercial research and education use, including for instruction at the authors institution and sharing with colleagues.

Other uses, including reproduction and distribution, or selling or licensing copies, or posting to personal, institutional or third party websites are prohibited.

In most cases authors are permitted to post their version of the article (e.g. in Word or Tex form) to their personal website or institutional repository. Authors requiring further information regarding Elsevier's archiving and manuscript policies are encouraged to visit:

http://www.elsevier.com/copyright 


\title{
Correlation between compression, tensile and tearing tests on healthy and calcified aortic tissues
}

\author{
Joris Walraevens ${ }^{\mathrm{a}, *}$, Bert Willaert ${ }^{\mathrm{b}}$, Gunter De Win ${ }^{\mathrm{c}}$, Andrea Ranftl ${ }^{\mathrm{a}}$, \\ Joris De Schutter $^{\mathrm{b}}$, Jos Vander Sloten ${ }^{\mathrm{a}}$ \\ ${ }^{a}$ Division of Biomechanics and Engineering Design, Katholieke Universiteit Leuven, Belgium \\ ${ }^{\mathrm{b}}$ Division of Production, Machine Design and Automatisation, Katholieke Universiteit Leuven, Belgium \\ ${ }^{\mathrm{c}}$ Center of Surgical Technologies, Katholieke Universiteit Leuven, Belgium \\ Received 20 December 2006; received in revised form 12 September 2007; accepted 30 January 2008
}

\begin{abstract}
An anastomosis performed in calcified tissues tears up faster than in healthy tissues. This study develops and validates an in vitro nondestructive method to distinguish healthy from calcified aortic tissues.

An uniaxial unconfined compression test is able to distinguish healthy from calcified aortas $(p<0.01)$. The compressive $E$-modulus at a strain level of $10 \%$ is $227 \pm 34 \mathrm{kPa}$ for artificially calcified and $147 \pm 15 \mathrm{kPa}$ for healthy porcine aortic tissues. Calcified aortic tissues have a lower tensile strength than healthy porcine aortic tissues $(p<0.05)$. The ultimate tensile strength is $1.34 \pm 0.18 \mathrm{MPa}$ and $1.55 \pm 0.31 \mathrm{MPa}$ for artificially calcified and healthy porcine aortic tissues respectively. Calcified aortic tissues have a lower resistance to tearing than healthy aortic tissues $(p<0.05)$. The resistance to tearing is $1.78 \pm 0.33 \mathrm{~N} / \mathrm{mm}$ and $2.16 \pm 0.64 \mathrm{~N} / \mathrm{mm}$ for artificially calcified and healthy porcine aortic tissues respectively.
\end{abstract}

(C) 2008 IPEM. Published by Elsevier Ltd. All rights reserved.

Keywords: Mechanical properties vascular tissues; Tensile test; Suture pull-out test; Compression test

\section{Introduction}

Cardiovascular disease (CVD) is responsible for approximately $30 \%$ of all deaths worldwide and claims more lives each year than the next six main causes of death combined [1,2]. Atherosclerosis is the most common disease of the arterial wall [3]. The atherosclerotic lesion partially or totally blocks the lumen, and decreases the blood supply to distal tissues. Several invasive and noninvasive procedures are available to revascularize an occluded artery [4-7], e.g. bypass operations where the narrowing caused by atherosclerosis is circumvented.

Anastomosis, i.e. a technique to connect healthy sections of tubular structures in the body after the diseased portion has been surgically removed, is performed during most car-

\footnotetext{
* Corresponding author at: Katholieke Universiteit Leuven, Division of Biomechanics and Engineering Design, Celestijnenlaan 300C, 3001 Heverlee, Belgium. Tel.: +32 16 328997; fax: +32 16327994 .

E-mail address: joris.walraevens@mech.kuleuven.be (J. Walraevens).
}

diovascular bypass surgeries. The advent of surgeon-aiding laparoscopic suturing devices, e.g. EndoStitch (US Surgical Inc., Norwalk, CT, USA) and robot-assisted laparoscopy, e.g. the master-slave system Da Vinci (Intuitive Surgical, Mountain View, CA, USA), allows a surgeon to perform anastomosis quicker than with manual laparoscopy [8-11], although opinions are sometimes contradictory $[12,13]$.

One of the challenges in the automatization of suturing is calcified atherosclerosis $[14,15]$. Tissues that suffer from calcified atherosclerosis often become more brittle [16,17]. Calcified plaques have unique mechanical properties [18,19]. They lower the tearing resistance and increase the risk of leaks [20-22]. To prevent tearing, the surgeon has to locate positions where the suture, clip or staple can be placed safely [23]. In classical open surgery, the surgeon locates the calcifications by manual palpation or by using a needle. However, due to the lack of haptic feedback inherent to laparoscopic suturing devices and master- slave systems, the surgeon is not yet capable of discriminating healthy from diseased tissues $[24,25]$. Several parameters have been proposed for 
automatic discrimination. The stiffness is probably the best parameter because its relative ease of acquisition. The static radial compressive modulus of atherosclerotic plaques is, unlike its circumferential tangential equivalent, significantly affected by the degree of calcification [26].

To date, no studies have been reported that compared healthy to calcified atherosclerotic aortic tissue. Studies of the overall mechanical behavior of excised atherosclerotic plaques are valuable $[3,18,27]$, but a discrimination method cannot be developed by merely testing excised plaques.

After cyclic preloading, i.e. preconditioning, soft tissues take on a steady-state behavior where the stiffness and the hysteresis in successive cycles is constant [28]. However, surgeons do not precondition tissues before operating [29]. Single-cycle loading has not been frequently reported. This study focuses on one cycle loading to simulate the clinical reality.

The purpose of this project was to develop and validate a non-destructive method that is able to distinguish healthy from calcified aortic tissue. Such a validated method can be of considerable use in future development of automated suturing devices and, moreover, contribute to an increased understanding of the biomechanics of diseased soft tissues.

\section{Methods}

\subsection{Specimen preparation}

Forty-five porcine abdominal aortas segments from healthy 6-to-8-month old pigs were obtained from a slaughter house. The pigs were sacrificed according to standard slaughtering procedure. After removal, each aorta was transported in isotonic physiological solution (Baxter, $0.9 \%$ sodium chloride). At the laboratory the aorta was dissected and the surrounding tissue removed. The control group was kept in physiological solution for $80 \mathrm{~min}$, while the test group I was perfused for $80 \mathrm{~min}$ in a dynamical environment with a calcifying solution which was developed in our laboratory (calciumphosphate ratio 5/3) [30]. After completion of the calcification process, a calciumphosphate layer was deposited in the aorta wall from the test group (up to $400 \mu \mathrm{m}$ deep). Normally, transport and sample preparation took no longer than $3 \mathrm{~h}$ before experiments could begin. Specimens were not frozen at any time during the procedure.

Nineteen samples of abdominal human aorta with calcified atherosclerosis were obtained during aneurism repair operations (UZ Leuven, Belgium). The samples were transported in physiological solution and were tested $5 \mathrm{~h}$ after removal (test group II).

\subsection{Experimental setting and protocol}

Each sample was tested only once. The samples were not preconditioned and experiments were performed at room temperature $\left(22^{\circ} \mathrm{C}\right)$. Data analysis was performed using Matlab 7.0. The data acquisition rate of force and displacement was $2 \mathrm{~Hz}$ for all experiments.

\subsubsection{Uniaxial unconfined compression}

Forty-five, forty, and nineteen samples were taken from the control group, test group I, and test group II respectively. Each tissue sample was cut into a $10 \mathrm{~mm} \times 10 \mathrm{~mm}$ strip using surgical scissors. The sample was indented by a cylindrical impermeable pounder $(\varnothing 6 \mathrm{~mm})$ (see Fig. 1). The movement of the pounder began $2.5 \mathrm{~mm}$ above the sample. During this uniaxial unconfined compression, the force was measured simultaneous to the displacement. The testing apparatus was a mini tensile/compression machine (Department of Metallurgy and Materials Engineering, KULeuven, Belgium). The loadcell had a range of $\pm 5 \mathrm{~N}$, with a resolution of $\pm 0.0025 \mathrm{~N}$. The indentation speed was $1 \mathrm{~mm} / \mathrm{min}$. To reduce the effects

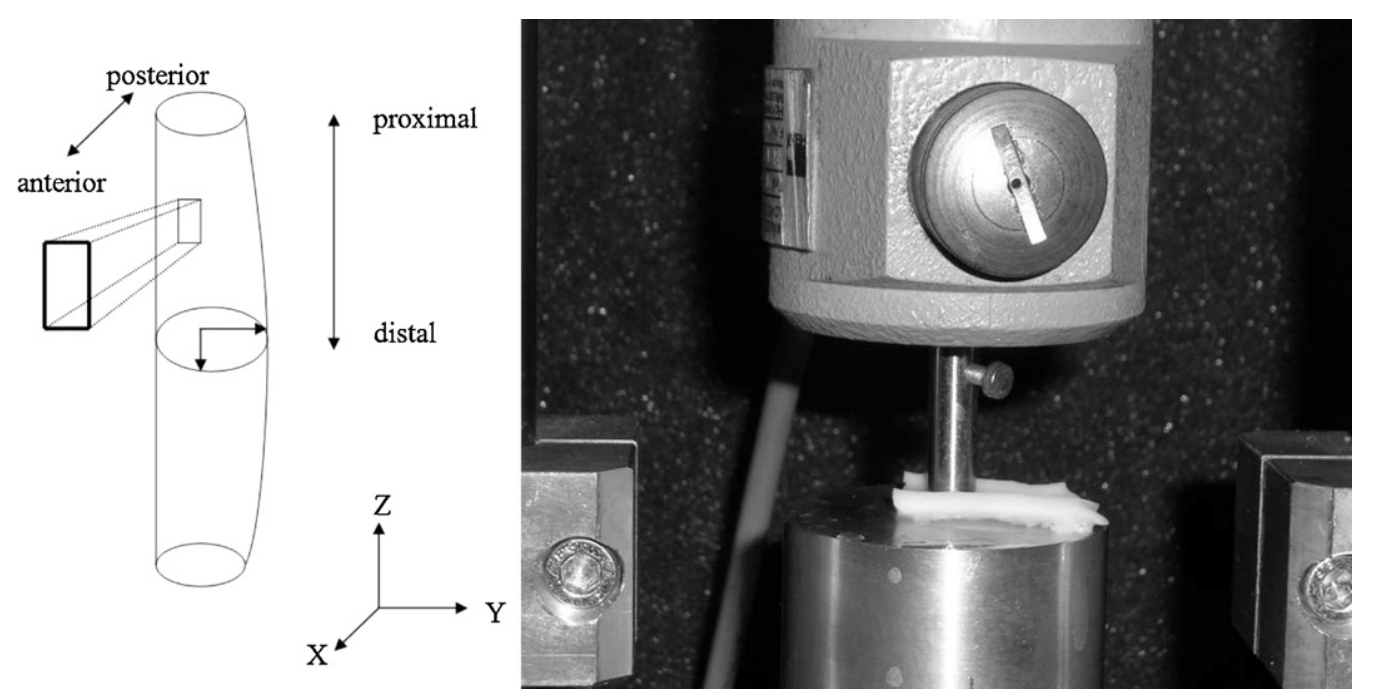

Fig. 1. Location of a sample of a abdominal aorta on a schematic representation (left). Set up for the uniaxial unconfined compression of healthy and calcified atherosclerotic porcine and human aortic tissue (right). 
of friction and to minimize drying of the specimen, a layer of isotonic physiological solution was provided between the sample and the pounder.

Only the results obtained from the loading phase are discussed. During each test the pounder was stopped after reaching a compression force of $4.8 \mathrm{~N}$ to prevent damage to the sample. From the force-displacement data a stress-strain curve was derived. The engineering stress (i.e. the vertical force divided by the cross-section area of the pounder) and strain (i.e. the current thickness divided by the initial thickness of the sample, which was determined at $0.5 \mathrm{~N}$ ) were calculated. A stress-strain curve was generated using the mean third order polynomial model parameters for each group $\left(\sigma=a_{3} \epsilon^{3}+a_{2} \epsilon^{2}+a_{1} \epsilon+a_{0}\right)$. The $E$-modulus was calculated as the strain-derivative of this curve.

\subsubsection{Uniaxial tensile test}

Seven and ten rectangular samples were taken from the control group and test group I respectively. Specimens from these samples were cut to the dumbbell shape $(4 \mathrm{~mm} \times 20 \mathrm{~mm})$ using a template and surgical scissors. Care was taken to avoid notches which might act as locations for stress concentrations. All samples were cut in the axial direction. Both ends of the sample were fixed using a set of grips, comprising two roughed plates clamped together (see Fig. 2). The displacement rate was $5 \mathrm{~mm} / \mathrm{min}$. The loadcell had a capacity of maximum $200 \mathrm{~N}$, with a resolution of $\pm 0.1 \mathrm{~N}$. The minimal area was calculated by measuring the thickness

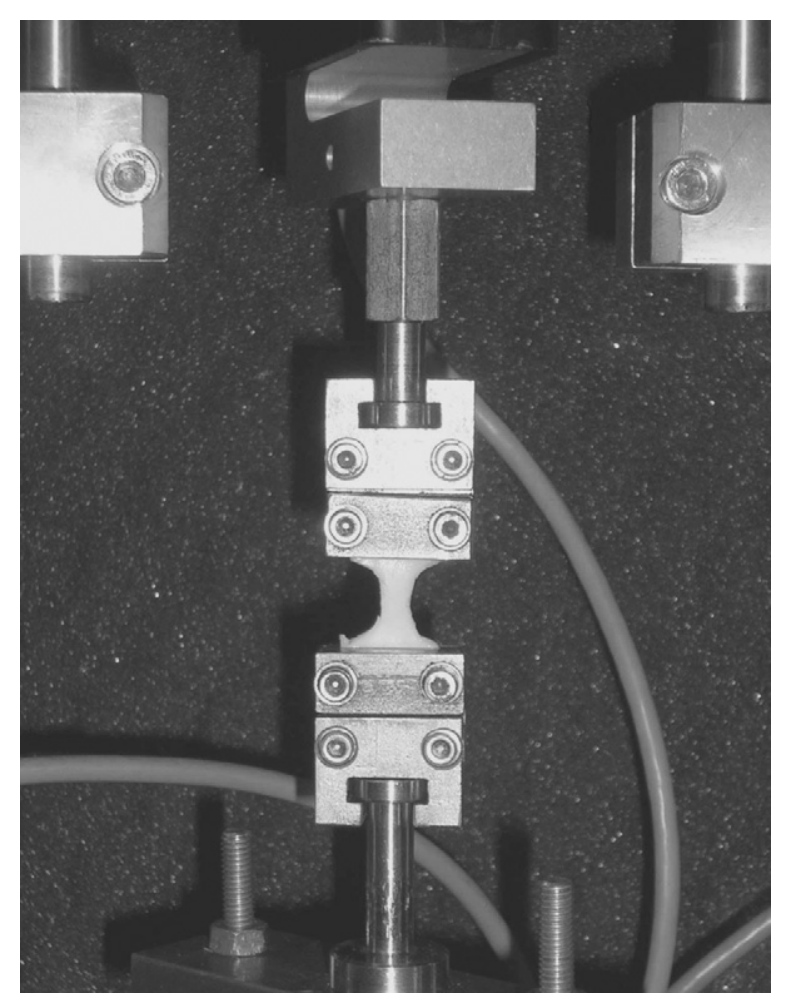

Fig. 2. Set up for the uniaxial tensile test of healthy and calcified porcine and human aortic tissue.

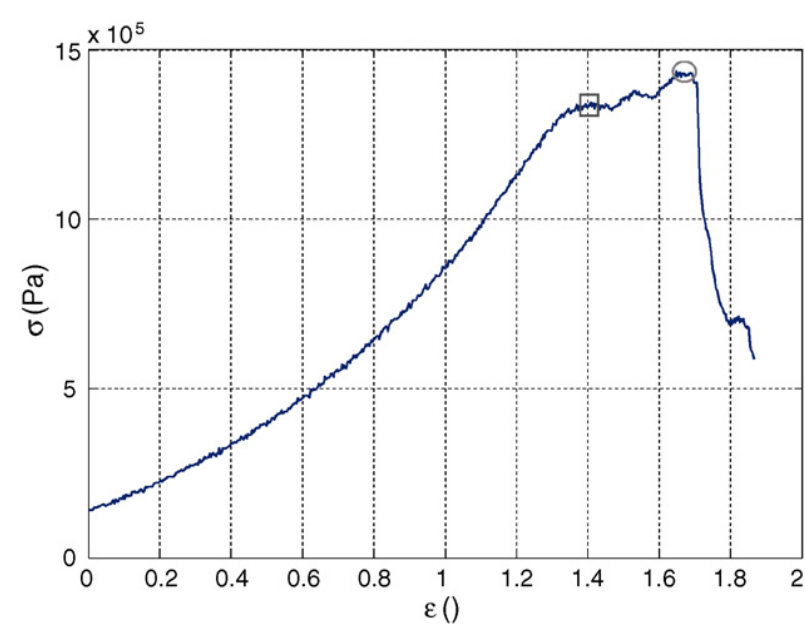

Fig. 3. Stress-strain relationship for a tensile test on porcine aortic tissue of test group I. $\sigma_{\mathrm{UTS}}$ and $\epsilon_{\mathrm{UTS}}$ are marked with a circle. $\sigma_{\mathrm{YP}}$ and $\epsilon_{\mathrm{YP}}$ are marked with a rectangle.

and width of the samples at the center point of the specimen using a micrometer, which has a precision of $10 \mu \mathrm{m}$ at $20^{\circ} \mathrm{C}$. The test was completed when the sample ruptured.

From the force-displacement data a stress-strain curve was derived. The engineering stress (i.e. the vertical force divided by the initial minimal cross-section area of the sample) and strain (i.e. the current length divided by the initial length of the sample, which was determined at $0.8 \mathrm{~N}$ ) were calculated. The ultimate tensile strength $\left(\sigma_{\text {UTS }}\right)$ and corresponding strain $\left(\epsilon_{\text {UTS }}\right)$ were determined for each sample. The ultimate tensile strength was taken as the peak stress obtained before specimen failure. The stress and strain on the yield point $\left(\sigma_{\mathrm{YP}}, \epsilon_{\mathrm{YP}}\right)$ were manually determined. The first tearing point was taken as the first local maximum. By way of example, Fig. 3 shows the stress-strain results of a tensile test on a sample of the control group.

\subsubsection{Tearing test}

Sixteen and nineteen rectangular samples were taken from the control group and test group I respectively. All samples were cut into a $20 \mathrm{~mm} \times 15 \mathrm{~mm}$ strip in the axial direction. One end of the sample was clamped. Through the other end a suture (2-0 Ethilon ${ }^{\circledR}$, Johnson and Johnson, Belgium) was placed in the center and $4 \mathrm{~mm}$ from the edge where the sample was clamped and a $5 \mathrm{~mm}$ loop was created (see Fig. 4). The displacement rate was $5 \mathrm{~mm} / \mathrm{min}$. The loadcell had a capacity of maximum $5 \mathrm{~N}$, with a resolution of $\pm 0.0025 \mathrm{~N}$. The thicknesses of the samples were determined by taking the measurement at the center point of the specimen using a micrometer, which has a precision of $10 \mu \mathrm{m}$ at $20^{\circ} \mathrm{C}$. The tests were continued until the suture was pulled out of the sample.

The resistance to tearing was expressed in Newton per millimeters, calculated, in agreement with the standard [31], according to the equation $T=\left(F_{\max } / d\right)$, where $T$ is the resistance to tearing, $F_{\max }$ is the maximum load in Newton, and $d$ is the thickness in millimeters. 


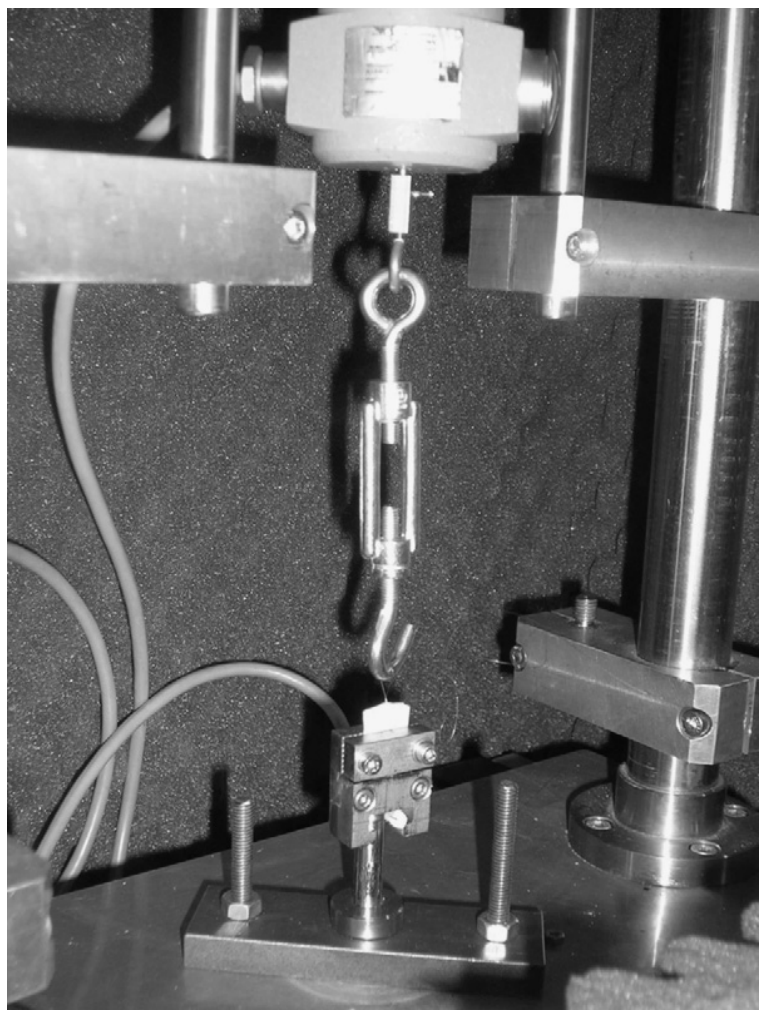

Fig. 4. Set up for the tearing test of healthy and calcified porcine and human aortic tissue.

\subsubsection{Statistical analysis}

The assumption of normality was controlled by a Kolmogorov-Smirnov test [32]. If the data were normal distributed, a Student $t$-test compared both groups. If the data were not normally distributed, a Mann Whitney $U$-test was used. $p<0.05$ was considered to be statistically significant. A Multivariate Discriminant Analysis model compared both groups based on multiple parameters [33]. Matlab 7.0 and Statistica 6.0 were used to carry out the statistical tests. The results for each series are expressed in terms of the mean and standard deviation.

\section{Results}

\subsection{Uniaxial unconfined compression}

Fig. 5 shows the relationship between the stress and strain, for healthy porcine aortic tissue (control group), artificially calcified porcine aortic tissue (test group I), and calcified human aortic tissue (test group II). The stress-strain curves are concave upward containing no linear portion from which a meaningful global elastic modulus could be determined.

The mean wall thickness of the samples of the control group and test group I were $1.58 \pm 0.30 \mathrm{~mm}$ and $1.65 \pm$ $0.21 \mathrm{~mm}$, respectively. The mean wall thickness of test group II was $1.84 \pm 0.28 \mathrm{~mm}$. There was no significant difference in wall thickness between the control group and test group

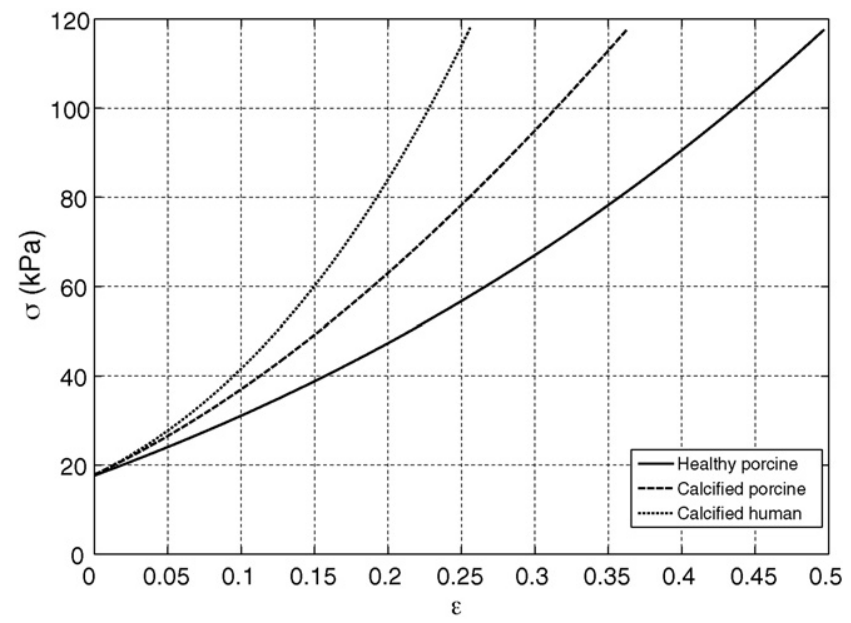

Fig. 5. Mean stress-strain relations for healthy aortic tissue (control group) versus calcified porcine aortic tissue (test group I), and calcified human aortic tissue (test group II).

I $(p>0.05)$. Significant difference in wall thickness was observed between test group II versus test group I and the control group $(p<0.05)$.

The mean stress as well as the elastic modulus for a compression strain of $10 \%$ is lower for healthy porcine aortic tissue than for artificially calcified porcine aortic tissue $(p<0.05)$ and than for calcified human aortic tissue (Figs. 6 and 7).

The multivariate discriminant analysis (MDA) was based on parameters $a_{3}$ and $a_{2}$, i.e. the coefficients of the third and second order term in the fitting. The a priori probability that a new sample would be allocated to the control group was equal to the a priori probability that a new sample would be allocated to test group I. MDA used 26 samples of the control group and 18 samples of test group I to define both groups. The remaining 19 and 22, respectively, were used to validate the analysis. Table 1 shows that the positive predictive value of the test was $94.4 \%$; only one sample was false positive. The

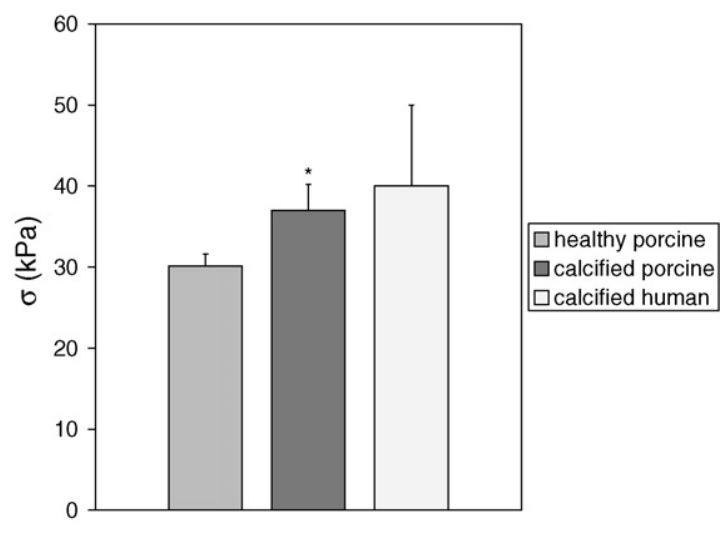

Fig. 6. Comparison of the stress for a compression strain of $10 \%$ of healthy porcine aortic tissue (control group), artificially calcified porcine aortic tissue (test group I), and calcified human aortic tissue (test group II) expressed in $\mathrm{kPa}$ * Significant different with respect to the control group $(p<0.05)$. 


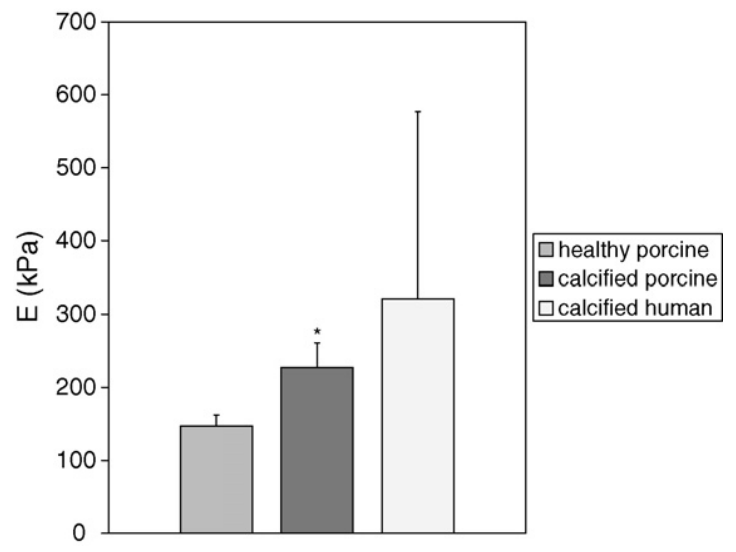

Fig. 7. Comparison of the $E$-modulus for a compression strain of $10 \%$ of healthy porcine aortic tissue (control group), artificially calcified porcine aortic tissue (test group I), and calcified human aortic tissue (test group II) expressed in $\mathrm{kPa}{ }^{*}$ Significant different with respect to the control group $(p<0.05)$.

negative predictive value was $100 \%$; there were no true negatives. The sensitivity of the test was $100 \%$ and the specificity was $95.7 \%$.

\subsection{Uniaxial tensile test}

The average thickness and width of the porcine specimens were $1.58 \pm 0.27 \mathrm{~mm}$ and $5.31 \pm 0.76 \mathrm{~mm}$ respectively. The stress at the yield point is smaller for artificially calcified porcine aortic tissue than for healthy porcine aortic tissue $(p<0.05)$, as shown in Fig. 8. The ultimate tensile strength is marginally significantly smaller for artificially calcified porcine aortic tissue $(p<0.1)$. There is no significant difference in strain (Fig. 9).

\subsection{Tearing test}

Artificially calcified porcine aortic tissue has a lower resistance to tearing compared to the healthy porcine aortic tissue $(p<0.05)$, as shown in Table 2 .

During tearing of the sample, failure is seen. The first sign of failure was the appearance of a small hole behind the suture. This was followed by a wedge spreading from the suture in the circumferential direction perpendicular to the axial axis (Fig. 10).

Table 1

Comparison of healthy porcine aortic tissue (control group) and artificially calcified porcine aortic tissue (test group I) using a multivariate discriminant analysis

\begin{tabular}{lcccr}
\hline & $\mathrm{n}$ & $\begin{array}{l}\text { Healthy } \\
\text { porcine }\end{array}$ & $\begin{array}{l}\text { Calcified } \\
\text { porcine }\end{array}$ & $\% \mathrm{PV}$ \\
\hline Healthy porcine & 19 & 18 & 1 & 94.7 \\
Calcified porcine & 22 & 0 & 22 & 100.0 \\
$\%$ SE/SP & & 100.0 & 95.7 & \\
\hline
\end{tabular}

$\mathrm{PV}$, predictive value; SE/SP, sensitivity/specificity.

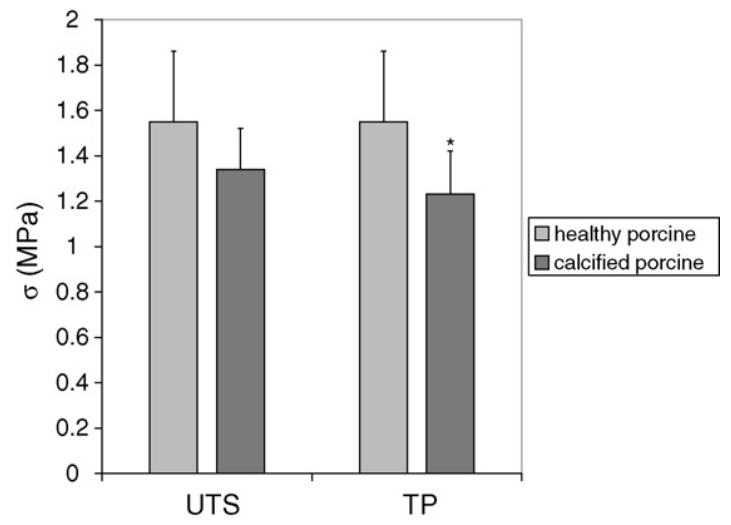

Fig. 8. Comparison of the ultimate tensile strength $\left(\sigma_{\text {UTS }}\right)$ and the stress at the yield point $\left(\sigma_{\mathrm{TP}}\right)$ of healthy porcine aortic tissue (control group) and artificially calcified porcine aortic tissue (test group I) expressed in $\mathrm{MPa} .{ }^{*}$ Significant different with respect to the control group $(p<0.05)$.

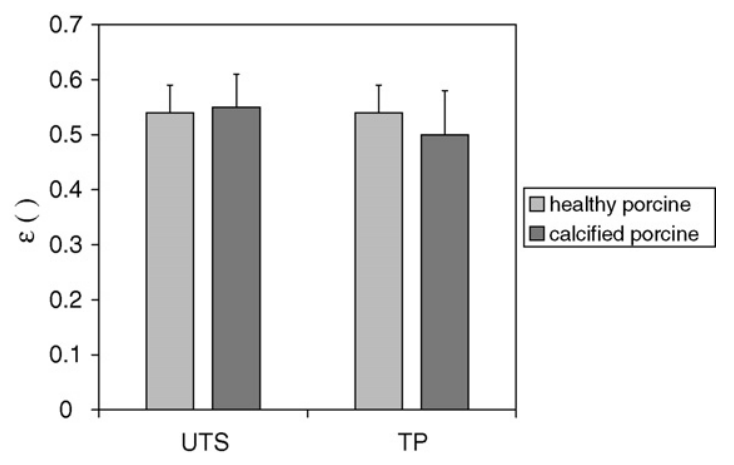

Fig. 9. Comparison of the ultimate tensile strain $\left(\epsilon_{\mathrm{UTS}}\right)$ and the strain at the yield point $\left(\epsilon_{\mathrm{TP}}\right)$ of healthy porcine aortic tissue (control group) and artificially calcified porcine aortic tissue (test group I).

Table 2

Comparison of the resistance to tearing of healthy aortic tissue (control group) and artificially calcified aortic tissue (test group I), expressed in Newton per millimeter

\begin{tabular}{lll}
\hline & $n$ & $T(\mathrm{~N} / \mathrm{mm})$ \\
\hline Healthy & 16 & $2.16 \pm 0.64$ \\
Artificially calcified & 19 & $1.78 \pm 0.33$ \\
$p$-Value & & $<0.05$ \\
\hline
\end{tabular}

mean \pm S.D.

\section{Discussion}

The purpose of this study was to develop a non-destructive method that is able to distinguish healthy from calcified aortic tissue. To verify whether the samples classified as calcified actually had a lower resistance to tearing, tensile tests and tearing tests validated the method.

Many published data on the mechanical properties of aortic tissues is available. They postulate that the stress-strain relationship of aortic tissues is non-linear, viscoelastic and different under tension and compression [31,34-36]. The behavior seen in the experiments was consistent with that 


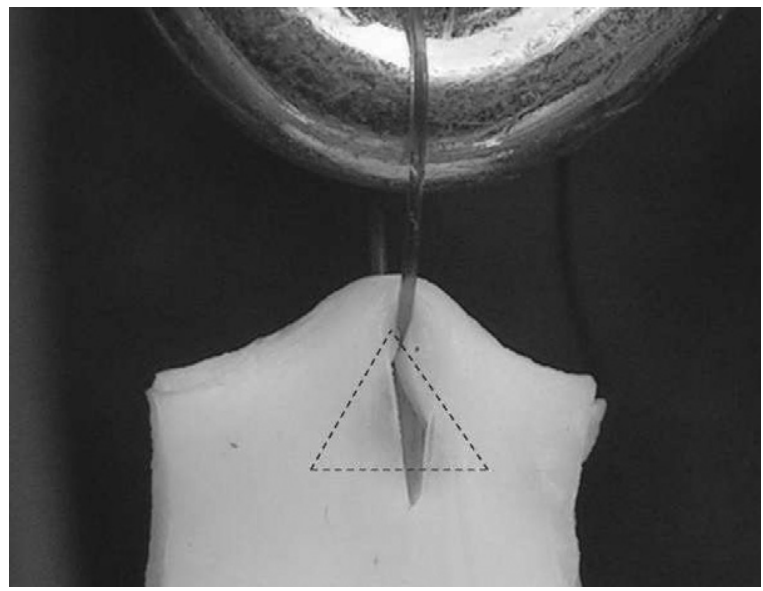

Fig. 10. Circumferential wedge propagation in healthy porcine aortic tissue due to a tearing force along the axial axis.

observed in previous studies. Few studies compared the biomechanical characteristics of healthy with calcified aortic tissues $[34,35]$. However, none of these aforementioned studies correlated the results of the tensile tests with a compression or tearing test.

Although a significant difference in mean wall thickness was observed between calcified human aortas versus healthy porcine and artificially calcified porcine aortas, no significant difference in mean wall thickness between healthy and artificially calcified porcine aortas was found. Because no control group of healthy human abdominal aortas could be obtained, it is not possible to allege that wall thickness might be a suitable parameter for distinguishing healthy from calcified aortas. The difference in mean wall thickness might be due to minor anatomical differences between porcine and human abdominal aortas.

The data suggest that calcified aortic tissue, porcine as well as human, has a higher compression stiffness than healthy aortic tissue. A MDA showed that a compression test is able to significantly discriminate healthy from calcified tissue in a non-destructive manner $(p<0.05)$. Tensile tests and tearing tests show that tissues that were classified by the compression test as calcified, had a lower ultimate tensile strength and a lower resistance to tearing ( $p<0.05$ ). These tissues would tear up faster during anastomosis.

Owing to a lack of human testing material, the discrimination method was developed and validated using porcine aortas. Few tests on calcified human aortic tissues confirmed the results of the porcine test. Because of the diversity in calcification in human aortic tissues [3,27] with respect to the homogeneity in calcification in artificially calcified porcine aortic tissues, human aortas show a significantly larger standard deviation than porcine aortas, both for compression stress and $E$-modulus as for ultimate tensile strain (Figs. 6, 7 and 9). No significant difference in compression stress and $E$-modulus is observed between artificially calcified porcine aortas and human aortas with calcified atherosclerosis $(p>$ $0.05)$.
The data are relevant to clinical procedures. On long time basis, the data can be incorporated in a master slave-slave system to compensate the lack of haptic feedback. The system can provide necessary information to the surgeon to discriminate healthy from diseased vascular tissue. On a short time basis, the data can be the base of the development of a laparoscopic discrimination device. The surgeon can use this device to locate the best suturing locations.

Because of the difference in mechanical behavior of soft tissues between tests in in vitro and in vivo conditions [29,37], the feasibility of the discrimination method still has to be studied in vivo before implementation in a robot-assisted system.

\section{Conclusion}

This study showed that a non-destructive uniaxial unconfined compression test is able to significantly discriminate healthy from calcified aortic tissue. The samples classified as calcified had a lower tensile strength and a lower resistance to tearing.

\section{Acknowledgments}

The authors gratefully acknowledge the support of Jan Demol and Stefan Vinckier.

\section{Conflict of interest}

None.

\section{References}

[1] Choi BG, Vilahur G, Yadegar D, Viles-Gonzalez JF, Badimon JJ. The role of high-density lipoprotein cholesterol in the prevention and possible treatment of cardiovascular diseases. Curr Mol Med 2006;6(5):571-87.

[2] Gaziano TA, Opie LH, Weinstein MC. Cardiovascular disease prevention with a multidrug regimen in the developing world: a cost-effectiveness analysis. Lancet 2006;368(9536):679-86.

[3] Salunke NV, Topoleski LD, Humphrey JD, Mergner WJ. Compressive stress-relaxation of human atherosclerotic plaque. J Biomed Mater Res 2001;55(2):236-41.

[4] Waller B, Orr C, Slack J, Pinkerton C, Tassel JV, Peters T. Anatomy, histology, and pathology of coronary arteries: a review relevant to new interventional and imaging techniques. Part I. Clin Cardiol 1992;15(6):451-7.

[5] Waller B, Orr C, Slack J, Pinkerton C, Tassel JV, Peters T. Anatomy, histology, and pathology of coronary arteries: a review relevant to new interventional and imaging techniques. Part II. Clin Cardiol 1992;15(7):535-40.

[6] Waller B, Orr C, Slack J, Pinkerton C, Tassel JV, Peters T. Anatomy, histology, and pathology of coronary arteries: a review relevant to new interventional and imaging techniques. Part III. Clin Cardiol 1992;15(8):607-15. 
[7] Waller B, Orr C, Slack J, Pinkerton C, Tassel JV, Peters T. Anatomy, histology, and pathology of coronary arteries: a review relevant to new interventional and imaging techniques. Part IV. Clin Cardiol 1992;15(9):675-87.

[8] Yohannes P, Rotariu P, Pinto P, Smith A, Lee B. Comparison of robotic versus laparoscopic skills: is there a difference in the learning curve? Urology 2002;60(1):39-45, discussion 45.

[9] Ishikawa N, Sun YS, Nifong LW, Ohtake H, Watanabe G, Chitwood WR. Robotic replacement of the descending aorta in human cadaver. Artif Organs 2006;30(9):719-21.

[10] Khairy GA, Fouda M, Abdulkarim A, Al-Saigh A, Al-Kattan K. A new era in laparoscopic surgery. Evaluation of robot-assisted laparoscopic procedures. Saudi Med J 2005;26(5):777-80.

[11] Ruurda JP, Wisselink W, Cuesta MA, Verhagen HJM, Broeders IAMJ Robot-assisted versus standard videoscopic aortic replacement a comparative study in pigs. Eur J Vasc Endovasc Surg 2004;27(5):501-6.

[12] Dakin GF, Gagner M. Comparison of laparoscopic skills performance between standard instruments and two surgical robotic systems. Surg Endosc 2003;17(4):574-9.

[13] Nio D, Bemelman WA, Balm R, Legemate DA. Laparoscopic vascular anastomoses: does robotic (Zeus-Aesop) assistance help to overcome the learning curve? Surg Endosc 2005;19(8):1071-6.

[14] Oz MC, Ashton RC, Singh MK, Serra JS, Lemole GM. Twelveyear experience with intraluminal sutureless ringed graft replacement of the descending thoracic and thoracoabdominal aorta. J Vasc Surg 1990;11(2):331-8.

[15] Oz MC, Ashton RC, McNicholas KW, Lemole GM. Sutureless ring graft replacement of ascending aorta and aortic arch. Ann Thorac Surg 1990;50(1):74-9.

[16] Ross MH, Romrell LJ, Kaye GI. Histology: a text and altas. 3rd ed. 1995.

[17] Syeda B, Gottsauner-Wolf M, Denk S, Pichler P, Khorsand A, Glogar D. Arterial compliance: a diagnostic marker for atherosclerotic plaque burden? Am J Hypertens 2003;16(5 Pt 1):356-62.

[18] Topoleski L, Salunke N, Humphrey J, Mergner W. Composition- and history-dependent radial compressive behavior of human atherosclerotic plaque. J Biomed Mater Res 1997;35(1):117-27.

[19] Chandran KB, Mun JH, Choi KK, Chen JS, Hamilton A, Nagaraj A, et al. A method for in vivo analysis for regional arterial wall material property alterations with atherosclerosis: preliminary results. Med Eng Phys 2003;25(4):289-98.

[20] Glagov S, Bassiouny HS, Sakaguchi Y, Goudet CA, Vito RP. Mechanical determinants of plaque modeling, remodeling and disruption. Atherosclerosis 1997;131(Suppl):S13-4.

[21] Haziza F, Papouin G, Barratt-Boyes B, Christie G, Whitlock R. Tears in bioprosthetic heart valve leaflets without calcific degeneration. J Heart Valve Dis 1996;5(1):35-9.
[22] Lendon C, Davies M, Richardson P, Born G. Testing of small connective tissue specimens for the determination of the mechanical behaviour of atherosclerotic plaques. J Biomed Eng 1993;15(1):2733.

[23] Miller K. Method of testing very soft biological tissues in compression. J Biomech 2005;38(1):153-8.

[24] Lee M, Nicholls H. Review article tactile sensing for mechatronics-a state of the art survey. Mechatronics 1999;9(1):1-31.

[25] Dario P. Tactile sensing: technology and applications. Sensors Actuators 1991;A26(1-3):251-6.

[26] Loree HM, Grodzinsky AJ, Park SY, Gibson LJ, Lee RT. Static circumferential tangential modulus of human atherosclerotic tissue. J Biomech 1994;27(2):195-204.

[27] Topoleski L, Salunke N. Mechanical behavior of calcified plaques: a summary of compression and stress-relaxation experiments. Z Kardiol 2000;89(Suppl 2):85-91.

[28] Fung Y. Biomechanics: mechanical properties of living tissues. 2nd ed New York: Springer Verlag; 1993.

[29] Brown JD, Rosen J, Kim YS, Chang L, Sinanan MN, Hannaford B. In-vivo and in-situ compressive properties of porcine abdominal soft tissues. Stud Health Technol Inform 2003;94:26-32.

[30] Willaert B, Walraevens J, Sloten JV, Schutter JD, Win GD. Intraoperative determination of the tissue quality for automatised suturing. In: 21st annual meeting of the Engineering and Urology Society, Atlanta, GA; 2006.

[31] Páez JM, Carrera A, Jorge E, Millán I, Cordon A, Maestro MA, et al Resistance to tearing of calf and ostrich pericardium: Influence of the type of suture material and the direction of the suture line. J Biomed Mater Res B Appl Biomater 2004;69(2):125-34.

[32] Massey F. The kolmogorov-Smirnov test for goodness of fit. J Am Stat Assoc 1951;46:68-78.

[33] Krzanowski WJ. Principles of multivariate analysis. Oxford University Press; 1988

[34] Vorp D, Schiro B, Ehrlich M, Juvonen T, Ergin M, Griffith B. Effect of aneurysm on the tensile strength and biomechanical behavior of the ascending thoracic aorta. Ann Thorac Surg 2003;75(4):1210-4.

[35] Martino ED, Geest JV, Gupta N, Makaroun M, Vorp D. Biomechanical properties of ruptured versus electively repaired abdominal aortic aneurysm wall tissue. J Vasc Surg 2006;43(3):570-6, discussion 576.

[36] Edwards MB, Draper ER, Hand JW, Young KMTIR. Mechanical testing of human cardiac tissue: some implications for MRI safety. J Cardiovasc Magn Reson 2005;7(5):835-40.

[37] Ottensmeyer MP, Ben-Ur E, Salisbury JK. Input and output for surgical simulation: devices to measure tissue properties in vivo and a haptic interface for laparoscopy simulators. Stud Health Technol Inform 2000;70:236-42. 